\title{
CONTRIBUTION TO THE KNOWLEDGE OF THE ROTIFER FAUNA (ROTIFERA: MONOGONONTA) FROM MINORCAN INLAND WATERS (BALEARIC ISLES: SPAIN)
}

\author{
J. De Manuel \\ Departament d'Ecologia, Facultat de Biologia, Universitat de Barcelona. Avda. Diagonal 645, 08028 Barcelona. \\ Spain.
}

Keywords: Rotifera, new records, Balearic, archipelago, biogeography, Spain.

\begin{abstract}
Forty-four species of rotifers have been identified in Minorca inland waters. Permanent ponds, temporary pools, flowing waters, and artificial pools were sampled. Most of the species are new records for the island and twentynine are new to the Balearic Isles. The families Brachionidae and Lecanidae provide half of the taxa. Keratella procurva (Thorpe, 1912), which is considered a subtropical species, occurred with a widespread distnbution in the island. Different taxa and «Formenkreis» found are mentioned. Original drawings and scanning photomicrographs of some species are presented. Typical assemblages of populations from every environment are also described.
\end{abstract}

\section{INTRODUCTION}

Traditionally, rotifers have been considered as cosmopolitan organisms of scanty biogeographical interest. However, an important degree of endemicity has been observed in species found in isolated areas from several latitudes (DumoNT, 1983). It suggests that the zoogeographical significance of rotifers cannot be undervalued.

Production of resting eggs, which may be carried by air or accidentally by migrating birds, as well as by «human transport», is an efficient strategy for freshwater colonization. This passive dispersal facilitates the origin of new populations from the parthenogenetic females, which have hatched from resting eggs, if there are favourable ecological conditions. Dependency of rotifers on abiotic factors, such as temperature, $\mathbf{p H}$, and salinity, is well-known (Hofmann, 1977). Throughout the year some populations replace others, and others occur with periodicity. Thus, the characterization of these limnetic environments is dif-

Limnetica, 6: 119-130 (1990)

(C) Asociación Española de Limnología, Madrid, Spain ficult if we are focusing on the rotifer communities.

Rotifers from the Balearic Isles have been insufficiently studied, the only records are from the works on freshwater biology by MARGALEF (1951, 1952, 1953), De Ridder (1967), and Pretus (1989).

The present paper adds new records to the knowledge of the rotifer fauna of Minorca. It investigates the occurrence of the species in the different habitat categories sampled, and discusses some biogeographical particularities.

\section{MATERIAL AND METHODS}

The study area, Minorca, located at the NE of the Balearic Isles, at $40^{\circ} \mathrm{N}$, in the Mediterranean Sea $\left(664 \mathrm{~km}^{2}\right.$ and a mean altitude of $\left.70 \mathrm{~m}\right)$, can be divided in two differentiated geological regions. The south and north-east parts of the island are constituted by calcareous and loamy sediments that are settled on horizontal strata (water disappears 
easily, and stagnates rarely; karstic formations and running waters occur). The second region, the rest of the island, is constituted by Palaeozoic and Mesozoic materials, mainly slates, sandstones and calcareous rocks. Here, lands are more undulating and conditions are better for the maintenance of small bodies of water. MARGALEF (1952) differentiates three regions or limnologic dominia in the island. Two of them belong to the geological zones mentioned, and the third comprises the littoral strip, where waters with high salinity occur. These regional waters are characterized by means of algal species assemblages.

Samples were collected in February, April and July 1987, from 40 sampling locations (fig. 1) corresponding to permanent and temporary ponds, flowing waters (ephemeral), and artificial waters (washing places, drinking troughs). All samples were collected with a 45 micrometer mesh plankton net, and preserved in $4 \%$ formaldehyde. Slides of subsamples were made for observation under microscope. Some were treated with sodium hypochlorite to identify the features of the trophi. Drawings were done with camera lucida. Selected individuals were observed under a scanning electron microscope (Cambridge S 120), having been previously subjected to dehydration (alcohol chain, critical point), and coating gold (sputtering method). (Amsellem \& Clement, 1980).

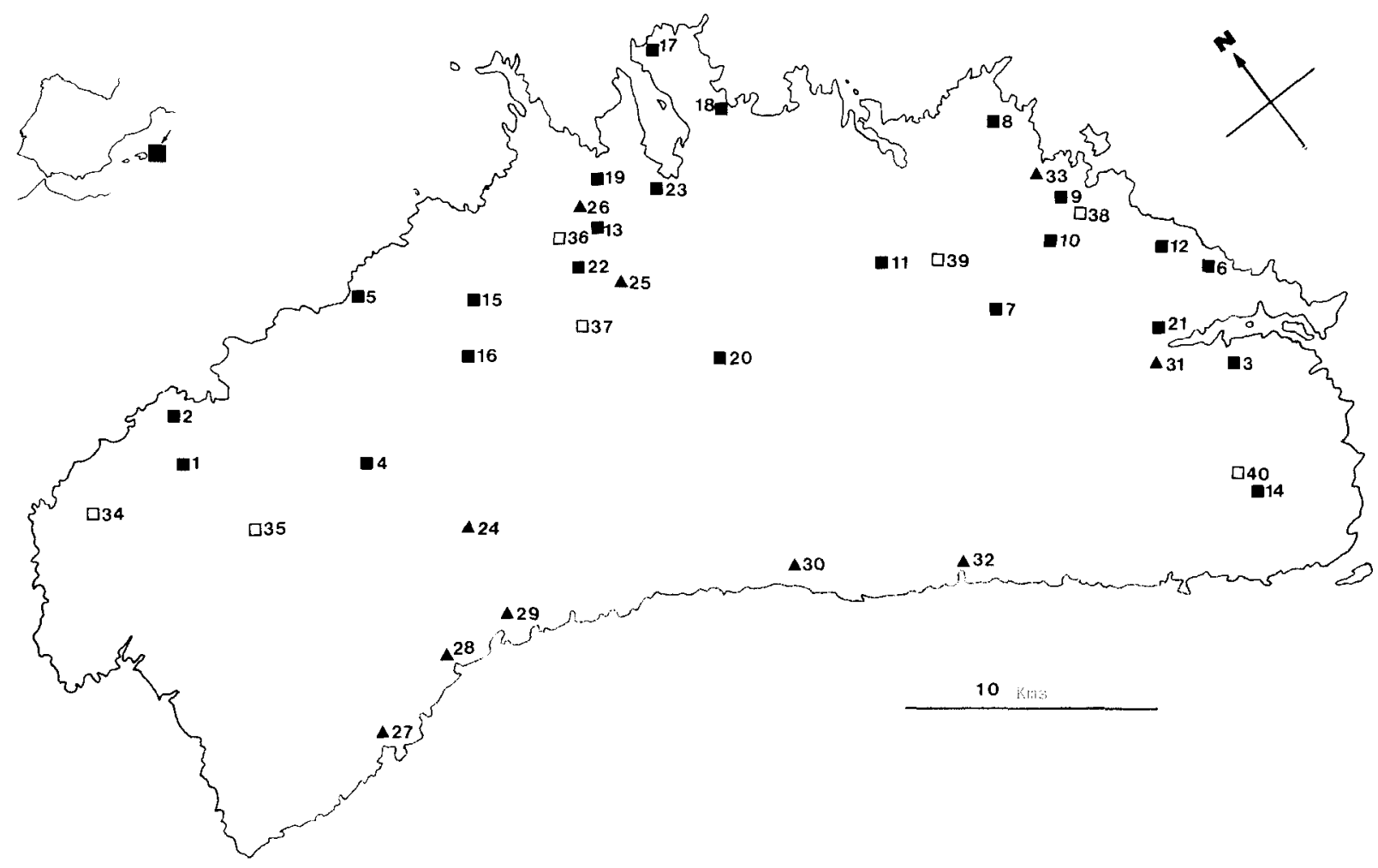

Figure 1.- Sampling sites in the island of Minorca: $\mathbf{p e r m a n e n t ~ p o n d s , ~ A ~ c u r r e n t ~ w a t e r s ~ o r ~ t e m p o r a l l y ~ p o n d s , ~} \mathrm{O}$ artificial waters (washing places, dnnking troughs...). 1, Binigafull; 2, Curniola; 3, bassa des Camí Verd; 4, Son Toni Martí; 5, Alocs; 6, Sa Mesquida; 7, Ullal des Puntarró; 8, Morella; 9, Sa Boal; 10, Camí Reial; 11, Clot des Guix; 12, arenal de Sa Mesquida; 13, Lluriach; 14, Alzinar de Torret; 15, Ullal de Son Abatzer; 16, Camí dels Alocs; 17, La Mola de Fornells; 18, Son Saura (Nord); 19, Prat de Lluriach; 20, Binillobet; 21, Sa Colàrsega de Maó; 22, Sa Cànova vella; 23, Salina de la Concepció; 24, Torrent de Sant Antoni; 25, Font de Montpalau; 26, Torrent de Llunach; 27, Son Saura (Sud); 28, Font de Macarella; 29, Barranc d'Algendar; 30, Barranc des Bec; 31, Torrent des Gorg; 32, Es Canutells; 33, Canal de Sa Torreta; 34, Son Bernedí; 35, Ses Arenetes; 36, Santa Creueta; 37, Montenegro; 38, Sa Boal Vella; 39, Egipte; 40, Torret.

Puntos de muestreo en la isla de Menorca: $\quad$ charcas permanentes, A aguas corrientes o charcas temporales, $\mathrm{O}$ cubetas artificiales. 


\section{RESULTS}

Faunistic aspects

The species found the localities where they were collected, and their relative abundance in each habitat category, are listed in table 1. Rotifers recorded were the following:

Fam. Brachionidae (11 spp)

The species and several morphs of the genus Brachionus that were found in the island, are shown in fig. 2. Brachionus bidentata f. testudinarius (Jakubsky, 1912) (fig. 2 d) (fig. 8 a) was the dominant species from localities 16 and 22. B. plicatilis Müller 1786 (fig. 2c) occurred in saline waters $\left(17,400 \mu \mathrm{S} \mathrm{cm}^{-1}-38,900 \mu \mathrm{S} \mathrm{cm}-{ }^{-}\right)$; it was collected in waters from Albufera des Grau in all seasons of the year (PRETUS, 1989). B. nilsoni Ahlstrom 1940 (fig. 2f,j) was found in locality 1, with some individuals infected by the microsporid parasite Bertramia asperospora (fig. 2f). B. calyciflorus Pallas 1776 (fig. 2,h) was very abundant in summer samples from locality 1; a morph variety was collected in locality 26: B. calyciflorus $\mathrm{f}$. dorcas (Gosse 1851) (fig. $2 \mathrm{~g}$ ). Two species of the genus Keratella occurred: Keratella quadrata (Müller, 1786) (fig. 3a), resembling the morph K. quadrata f. dispersa (Carlin, 1943), only observed in spring at locality 3; and small forms (length $140-160 \mathrm{pm}$ ) of the subtropical species $K$. procur$v a$ (Thorpe, 1912) (fig. 3b) (fig. 8c), with a distinct pentagonal posteromedian plaque (fig. 8d), that were collected in humic ponds from localities 20,30 , and in small artificial waters from locations 35 and 38. Small individuals (80-90 $\mu \mathrm{m}$ length) of the species Anuraeopsis fissa (Gosse, 1851) (fig. $\left.2 \mathrm{~d}, \mathrm{~d}^{\prime}\right)$ (fig. $8 \mathrm{~b}$ ) were found. The cold stenothermous species Notholca squamula (Müller, 1786) occurred in the winter samples of a permanent pond.

\section{Fam. Euchlanidae (1 sp)}

This family only provided one cosmopolitan species, Euchlanis dilatata (Ehrenberg, 1832), which presented a notable variability in shape and size. It was common among macrophytes.

Fam. Mytilinidae (2 spp)

Two species (often coexisting) were observed: large specimens (length: 145-180 $\mu \mathrm{m}$, width: 60-85 $\mu \mathrm{m})$ of the species Mytilina ventralis (Ehrenberg, 1832) (fig. 3g,g') (fig. 8e) were found in benthic samples from localities 7 and 26; and Lophocharis salpina (Ehrenberg, 1834) (fig. 3f,f') (fig. 8f), which showed shape variability, with intermediate forms to L. oxysternon (Gosse, 1851).

Fam. Trichotriidae (1 sp)

Trichotriapocillum (Müller, 1776) (fig. 2e): specimens were found in flowing waters; it is a plankton migrant form benthic and littoral areas that lives among macrophytes.

Fam. Colurellidae (2 spp)

Colurella adriatica Ehrenberg 1831 (fig. 2h,h') occurred in ponds and streams near the littoral strip. Lepadella patella (Müller 1786) (fig. 2j,k) was the most common rotifer in the island; it is a typical plankton migrant, cosmopolitan, eurythermic and euryhaline. It occurred in $35 \%$ of the localities.

Fam. Lecanidae (11 spp)

This family provided many species in the Minorca rotifer fauna. Most are cosmopolitan and very common in freshwater habitats. Taxa found in the island are shown in fig. 4. All Lecanidae species are littoral and benthic (HARRING \& Myers, 1926). Some specimens of Lecane (M.) bifurca (Bryce, 1892) (fig. 4i) were observed in summer from locality 11 , a pond with water on chalk sediments. L.(M.) bulla (Gosse, 1886) (fig. 4c) is a littoral species that occasionally occurred in plankton. L.(M.) closterocerca (Schmarda, 1859) (fig. 41) is one of the most common benthic rotifers, but it was frequently observed in plankton samples. The small L.(M.) pyriformis Daday 1905 (fig. 4o) was collected in a karstic pool from locality 27 . One specimen of the species L.(M.) quadridentata (Ehrenberg, 1832) (fig. 4g) was found in summer samples from locality 27 . The species L. luna (Müller, 1776) (fig. 4a,b) (fig. 8g,h), a widespread rotifer in the island, presented two morphs: one constituted by animals with almost circular dorsal plate (fig. 4a), and the other morph presenting a more elongated body (fig. 4b). Both can coexist, but the latter is less frequent. A large population of L. ohioensis (Herrick, 1885) (fig. 4d) was found in summer from locality 5. It can belong to the variant L. ichthyoura (Anderson \& 
Table 1. Rotifera collected from Minorca. ${ }^{*}$ new record for the island. $\bullet$ new record for Balearic Isles. Ocurrence is shown by $+=$ rare (one locality), $++=$ frequent $(>10 \%$ localities). Localities were each species were collected are indicated with their number (fig. 1).

\begin{tabular}{|c|c|c|c|c|}
\hline Species & $\begin{array}{l}\text { Permanent } \\
\text { ponds }\end{array}$ & $\begin{array}{l}\text { Temporary } \\
\text { ponds } \\
\text { or streams }\end{array}$ & $\begin{array}{l}\text { Artificial } \\
\text { waters }\end{array}$ & Localities \\
\hline Anuraeopsis fissa Gosse, 1851*• & ++ & & ++ & $4,9,10,11,34,40$ \\
\hline Brachionus angularis Gosse, 1851 $^{\star} \bullet$ & ++ & & + & $1,8,10,11,36$ \\
\hline B. bidentata f. testudinarius (Jakubsky, 1912) ${ }^{*} \bullet$ & & +t & & 6,22 \\
\hline B. calyciftorus Pallas, $1776^{*} \bullet$ & + & + & & 1,26 \\
\hline B. nilsoni Ahlstrom, $1940^{*} \bullet$ & + & & & 1 \\
\hline B. plicatilis Müiier, $\mathbf{1 7 8 6}$ & ++ & & & 12,23 \\
\hline B. quadridentatus Hermann, $1873^{*}$ & ++ & + & & $14,16,26$ \\
\hline B. urceolaris (Müiier, 1773) & ++ & & & 17,20 \\
\hline Cephalodella catellina (Müller, 1786)* & ++ & + & + & $7,13,24,26,35$ \\
\hline C. gibba (Ehrenberg, 1838)' & ++ & + & & $9,13,24$ \\
\hline C. ventripes Dixon-Nutall, $1901^{*} \bullet$ & ++ & & & 2,6 \\
\hline C. sp. & & + & & 27 \\
\hline Colurella adriatica Ehrenberg, 1831 & & + & + & 29,32 \\
\hline Eosphora najas Ehrenberg, $1830^{*} \bullet$ & + & & & 7 \\
\hline Euchlanis dilatata (Ehrenberg, 1832) & ++ & ++ & & $5,15,18,24,26,27$ \\
\hline Filinia longiseta (Ehrenberg, 1824)*• & ++ & & & $1,16,20$ \\
\hline Hexarthra fennica Levander, 1892 & $+t$ & & ++ & $16,36,40,12$ \\
\hline Hexarthra mira (Hudson, 1871)*• & + & & & 11 \\
\hline Keratella procurva (Thorpe, 1912)*• & + & + & ++ & $20,30,35,38$ \\
\hline Keratella quadrata (Müller, 1786)*• & + & & & 3 \\
\hline Lacinularia elliptica Shephard, 1879*• & + & & & 2 \\
\hline Lecane (M.) bifurca (Bryce, 1892)*• & + & & & 11 \\
\hline L. (M.) bulla (Gosse, 1886$)^{*} \bullet$ & ++ & + & ++ & $11,24,27,30,34,35,40$ \\
\hline L. (M.) closterocerca $\mathbf{S c h m a r d a ,} \mathbf{1 8 5 9}$ & ++ & ++ & ++ & $\begin{array}{l}4,7,8,9,11,13,19,24,25,26,27,29,30 \\
32,35,39,40\end{array}$ \\
\hline L. (M.) furcata Murray, $1913^{*} \bullet$ & & & + & 36 \\
\hline L. (M.) hamata Stokes, $1896^{*} \bullet$ & & ++ & & 27,30 \\
\hline L. (L.) luna (Müller, 1776) & ++ & ++ & ++ & $5,7,9,11,13,19,27,30,31,34,35,37,38,40$ \\
\hline L. (L.) nana (Murray, 1913)*• & ++ & + & + & $5,6,7,11,27,36$ \\
\hline L. (L.) ohioensis (Herrick, 1885)*• & + & & & 5 \\
\hline L. (M.) punctata (Murray, 1913)*• & & & + & 34 \\
\hline L. (M.) pyriformis Daday, $1905^{*} \bullet$ & & + & & 27 \\
\hline L. (M.) quadridentata (Ehrenberg, 1832)*• & & + & & 27 \\
\hline Lepadella patella (Müller, 1786) & ++ & ++ & ++ & $4,5,7,11,13,15,16,24,27,31,32,35,39,40$ \\
\hline Lophocharis salpina Ehrenberg, $1834^{*} \bullet$ & ++ & + & & $7,8,13,16,26$ \\
\hline Mytilina ventralis (Ehrenberg, 1832)*• & + & + & & 7,26 \\
\hline Notholca squamula (Müller, 1786) & + & & & 16 \\
\hline Polyarthra dolichoptera Idelson, $1925^{*} \bullet$ & ++ & & ++ & $1,2,9,11,38$ \\
\hline P. remata $(\text { Skonkov, } 1846)^{*} \bullet$ & ++ & & & 1,11 \\
\hline Proales sigmoidea (Skorikov, 1896)* & + & & & 18 \\
\hline Testudinella patina (Hermann, 1783) & ++ & ++ & & $5,7,8,13,16,20,24,26,33$ \\
\hline Trichocerca intermedia (Stenroos, 1898)* & + & & & 13 \\
\hline T. musculus Hauer, $1935^{*} \bullet$ & & + & & 25 \\
\hline T. pusilla (Lauterborn, 1898)* & ++ & & & 1,4 \\
\hline T. rattus (Müller, 1776) & + & & ++ & $13,36,40$ \\
\hline T. rattus f. carinata (Ehrenberg, 1830) & ++ & & & $1,13,15$ \\
\hline T. $s p$ & + & & & 4 \\
\hline Trichotria pocillum (Müller, 1776)*• & & ++ & & 25,30 \\
\hline Bdelloidea & ++ & ++ & ++ & \\
\hline
\end{tabular}




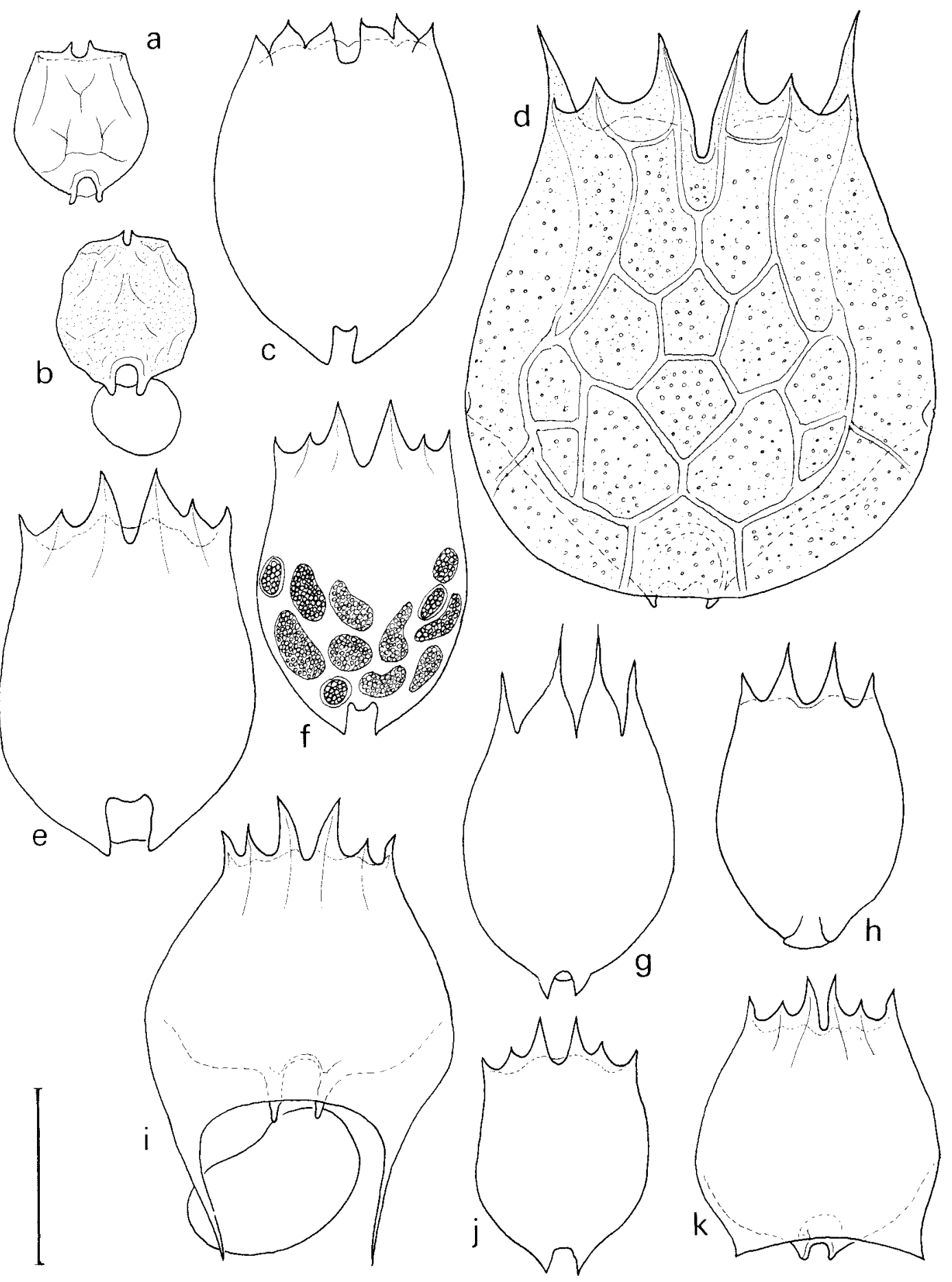

Figure 2.- Species of genus Brachionus: a) B. angularis (loc. 36);b) B. angularis (loc. 10); c) B. plicatilis (loc. 23); d) B. bidentata f. testudinarius (loc. 16); e) B. urceolaris (loc. 17);f,j) B. nilsoni infected by Bertramia asperospora (loc. 1); g) B. calyciflorus $\mathrm{f}$. dorcas (loc. 26); h) B. calyciflorus (loc. 1); i) B. quadridentatus quadridentatus (loc. 14); $k$ ) B. quadridentatus $\mathrm{f}$. brevispinus (loc. 26). Scale bar $=100 \mu$. 
Shephard, 1892), that was synomized with L. ohioensis by KOSTE (1978). It presents a clear fishtail forrn of the caudal process.

\section{Fam. Proalidae (1 sp)}

One specimen of Proales sigmoidea (Skorikov, 1896) (fig. 5e,f,g) was observed in spring samples from locality 18 , a perrnanent pond with distrophic waters on the northern coast of the island.
Fam. Notommatidae (4 spp)

This family provided some littoral and benthic forms, occasionally migrants in the plankton. The species Cephalodella gibba (Ehrenberg, 1838) (fig. $6 \mathrm{~m}, \mathrm{~s})$, C. catellina (Müller, 1786) (fig. 6n,o,p), C. ventripes Dixon-Nuttall, 1901 (fig. 6t,u,v) and an unidentified species of Cephalodella (fig. 6q), were coliected from ponds with abundant macrophytes. One specimen of the predatory rotifer

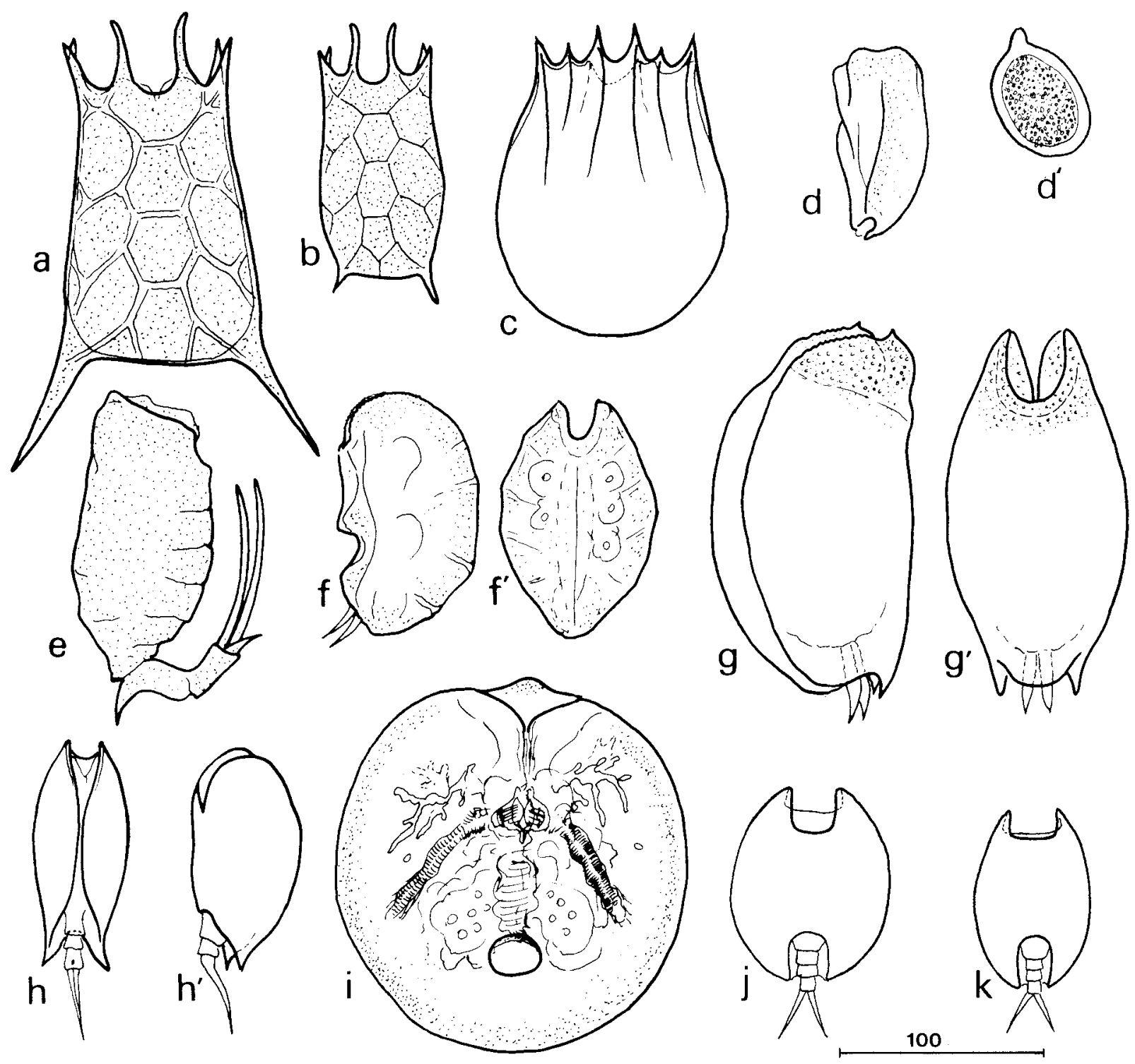

Figure 3.- a) Keratella quadrata (loc. 3); b) K. procurva (loc. 20); c) Notholca squamula (loc. 16); d) Anuraeopsis fissa (loc. 9); d') egg of $A$. fissa; e) Trichotria pocillum (loc. 25); f) Lophocharis salpina (lat., loc. 26); f) L. salpina (dors.);g) $M$ ytilina ventralis (lat., loc. 26); g') M. ventralis (vent.); h) Colurella adriatica (vent., loc. 32); h') C. adriatica (lat.); i) Testudinella patina (loc. 8); $\mathrm{j}, \mathrm{k}$ ) Lepadella patella (loc. 5 and 15 respec.). Scale in $\mu \mathrm{m}$. 
Eosphora najas Ehrenberg 1830 (fig. 5a,b,c,d) was found in summer in locality 7 .

Fam. Trichocercidae (4 spp)

Trichocerca rattus (Müller, 1776) (Fig. 6e,f) occurred in some samples from artificial waterbodies; and a second morph was found in winter. This one corresponded to the «Formenkreis» T. rattus f. carinata (Ehrenberg, 1830) (fig. 6c,d), with a dorsal crest and a long left toe (MARGALEF found this species in 1952, calling it T. cf. carinata). Few individuals of the species $T$. intermedia (Stenroos, 1898) (fig. 6h,i), were found coexisting with $\boldsymbol{T}$. rattus f. carinata at sampling site 13. An unidentified species of Trichocerca (fig. 61) was collected in locality 4 . Its lenght is $65 \mu \mathrm{m}$ and it presents three toes: $30 \mu \mathrm{m}, 10 \mu \mathrm{m}$ and $6 \mu \mathrm{m}$ in length. Only one specimen was found.
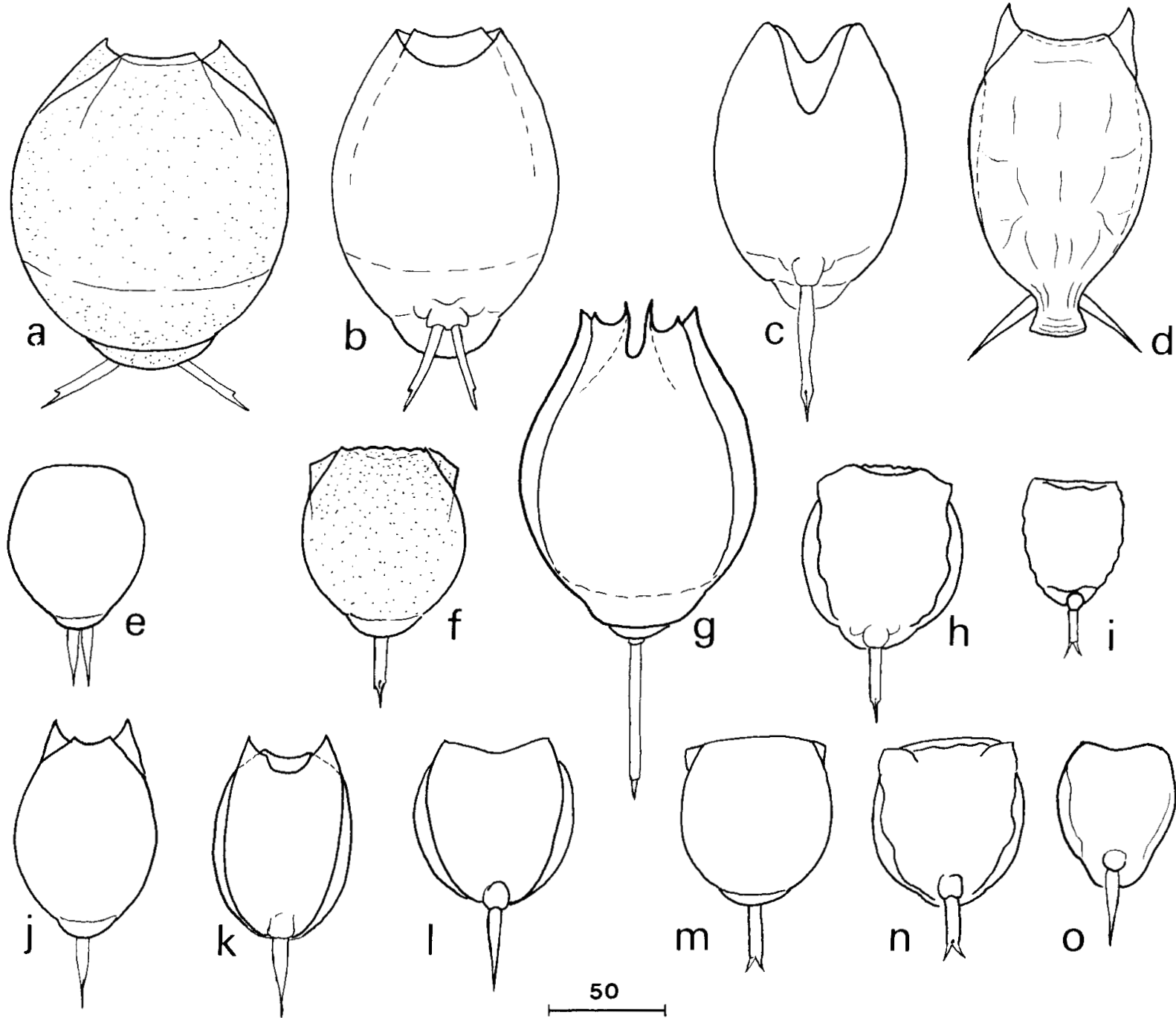

Figure 4.- Lecanidae from Minorca: a) Lecane luna (dors., loc. 5); b) L. luna (vent., loc. 7); c) L. bulla (vent. loc. 11); d) L. ohioensis (dors., loc. 5); e) L. nana (dors., loc. 36); f) L. punctata (dors., loc. 34); g) L. quadridentata (dors., loc. 27); h) L. punctata (vent., loc. 34); i) L. bifurca (dors., loc. 11); j,k) L. hamata (dors. vent. respec., loc. 30); 1) L. closterocerca (vent., loc. 27); m,n) L. furcata (dors. \& vent. respec., loc. 36); o) L. pyriformis (vent., loc. 27). Scale in $\mu \mathrm{m}$. 
Fam. Synchaetidae (2 spp)

Polyarthra dolichoptera Idelson, 1925 presented intermediate forms to P. vulgaris Carlin 1943. They could be distingued by the shape and size of their paddles. Some resting eggs of $P$. dolichopte$r a$ were observed in the summer samples from locality 1 . Coexistence with $P$. remata (Skorikov, 1896) was observed in the ponds from localities 1 and 11 .

Fam. Testudinellidae (1 sp)

Testudinella patina (Hermann, 1783) (fig. 3i), a cosmopolitan species, occurred occasionally in the plancton; its population was concentred in the phytobenthic zone. It was a widespread rotifer in Minorcan inland waters.

Fam. Flosculariidae (1 sp)

Lacinularia elliptica Shephard, 1897 (fig. 7), a colonial planktonic rotifer, was collected from sample location 2 , a temporary pond with turbid waters. It presented colonies with many indivi- duals, generally constituted by 60 to 150 rotifers. Members of the colony were situated around a stalk in an ellipsoid distribution.

\section{Fam. Hexarthridae (2 spp)}

Hexarthra fennica Levander 1892 and H. mira (Hudson, 1871), both warm stenotherm species, were collected in summer. H. fennica was found in some artificial pools and in brackish waters.

\section{Fam. Filiniidae (1 sp)}

The planktonic species Filinia longiseta (Ehrenberg 1834) occurred in Minorca. It was collected the morph Filinia longiseta var. limnetica (Zacharias, 1893); a population of this rotifer reached a high density in spring samples from locality 20, and some males were observed.

Contracted Bdelloidea (Digononta) were observed in the most of the samples, but they could not be identified in preserved material. (Only living Bdelloidea can be identified with certainty).
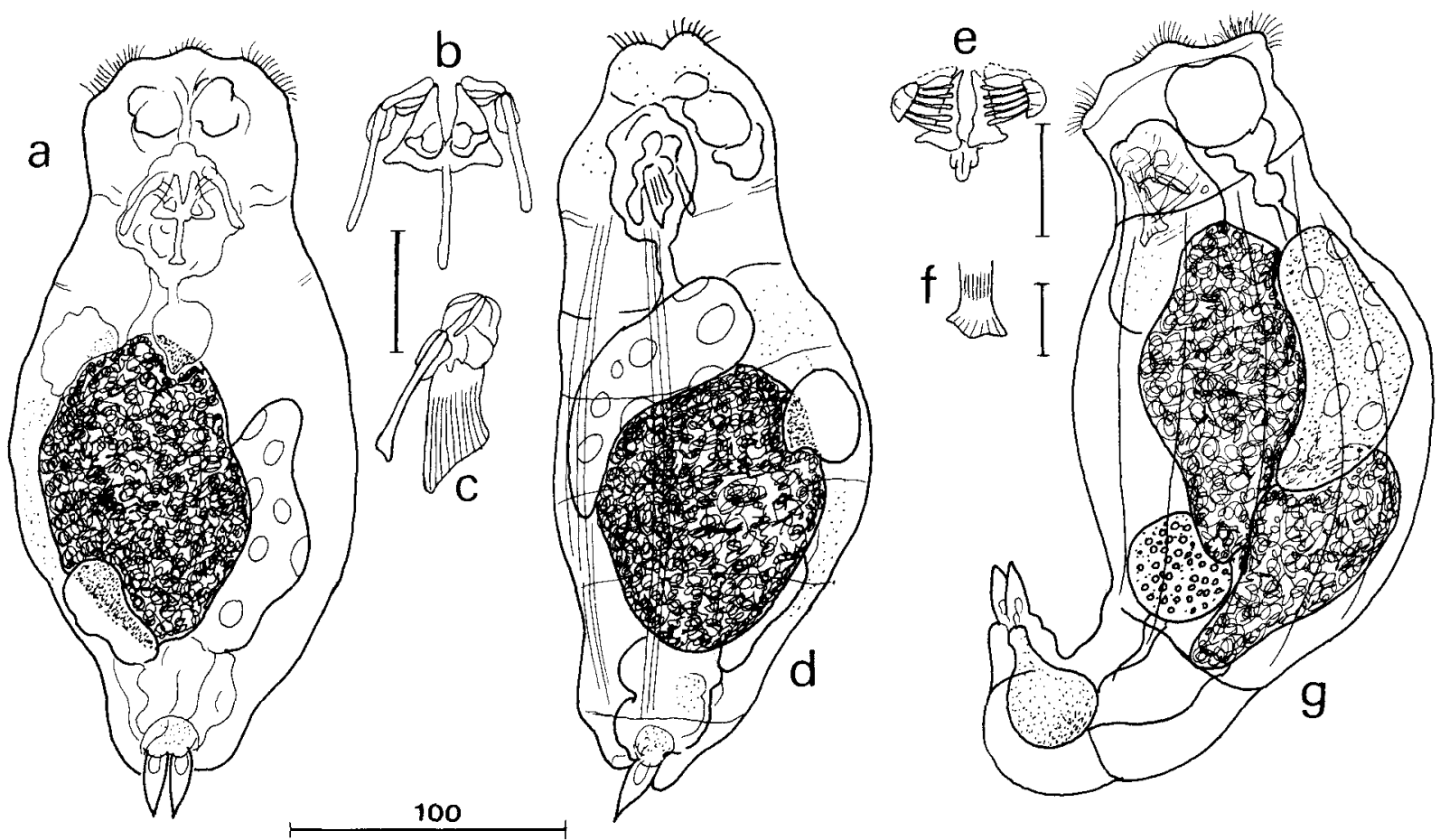

Figure 5.- a) Eosphora najas (loc. 7);b,c) E. najas, frontal and lateral view of mastax; d) E. najas (lateral); e) Proales sigmoidea, mastax; f) detail of the fulcrum; g) P. sigmoidea (loc. 18 ). Scale in $\mu \mathrm{m}$. 


\section{Assemblages and habitats}

From 1-12 rotifers occurred in each locality (mean: 5.26) A comparison of the rotifer assemblages demonstrates remarkable heterogeneity of the three habitat categories: a) Permanent ponds

Mean: $4.77 \mathrm{spp} /$ pond. Planktonic rotifers may be successful and colonize the water of permanents ponds. Species of Brachionus, Keratella, Polyarthra, Hexarthra and Filinia frequently occurred in these environments. Some benthic spe-
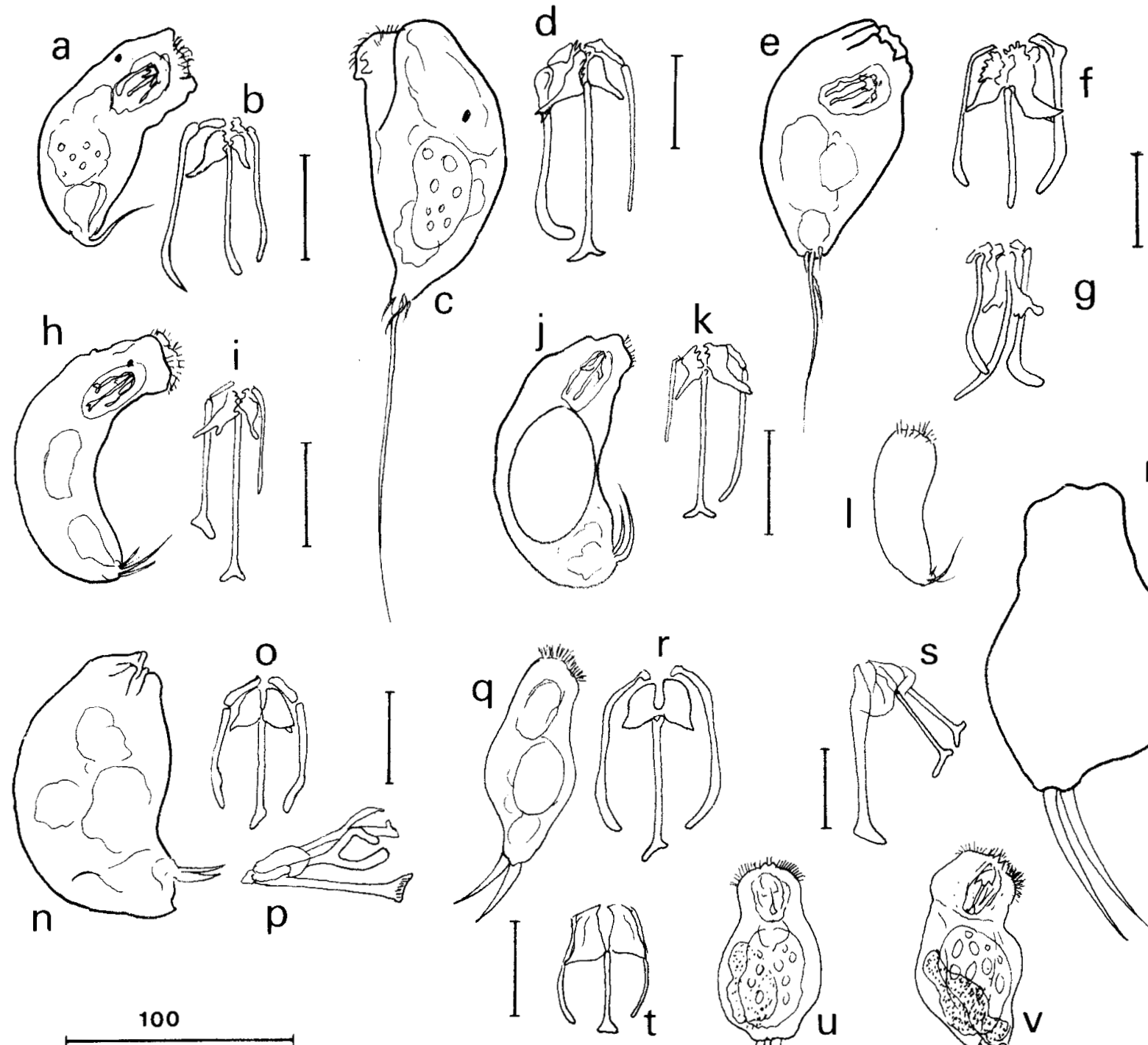

9
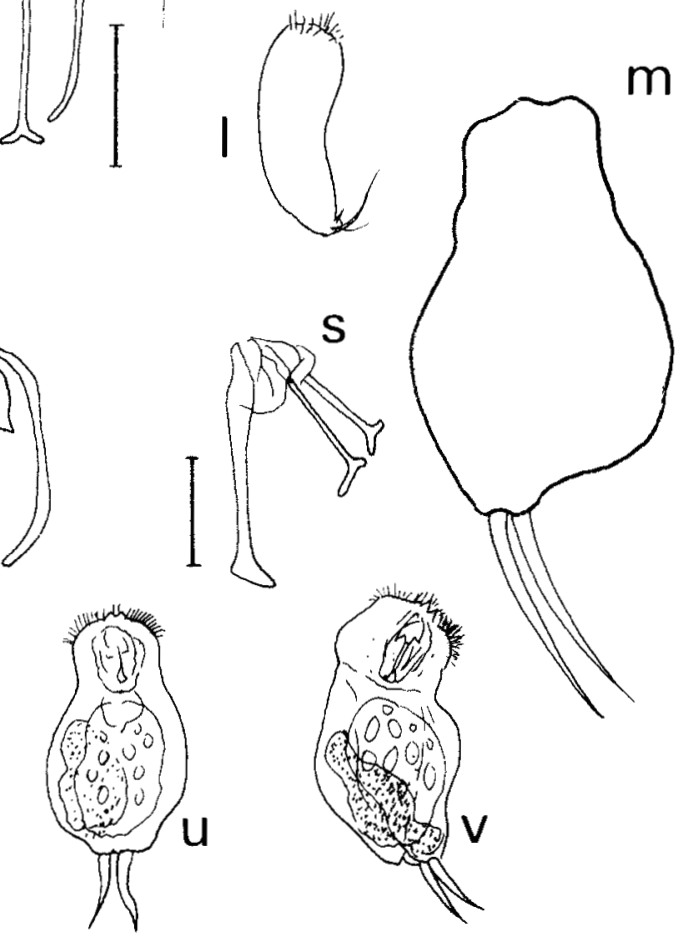

Figure 6.- a) Trichocerca pusilla (loc. 1); b) mastax of a; c) T. rattus f. carinata (loc. 13); d) mastax of c; e) T. ratus (loc. 36);f,g) mastax of e; h) T. intermedia (loc. 13); i) mastax of $\mathrm{h} ; \mathrm{j}$ ) T. musculus (loc. ); $\boldsymbol{k}$ ) mastax of $\mathrm{j}$; 1) T. sp (loc. 4); m) Cephalodella gibba (loc. 9); s) mastax of $\mathrm{m} ; \mathrm{n}$ ) C. catellina (loc. 7); o,p) rnastax of $\mathrm{n} ; \mathrm{q}$ ) C. sp. (loc. 27); r) mastax of q; u) C. ventripes (loc. 2); v) C. ventripes (lateral); t) mastax of $\mathbf{u}, \mathbf{v}$. Vertical scale bar $20 \mu \mathrm{m}$. Scale in $\mu \mathrm{m}$. 
cies occurred in the plankton of these waterbodies, mainly Lecanidae. Brachionus bidentata f. testudinarius, B. plicatilis, B. urceolaris and B. quadridentatus $\mathrm{f}$. brevispinus were found to constitute large populations in every case. These populations were the dominant species in some pools. Then, zooplankton biomass is constituted mainly by these rotifers. The same is observed of the colonial planktonic rotifer Lacinularia elliptica, which was found thoughout the year in a turbid pool of the west of the island. Some assemblages have been found repeatedly in rotifer communities from some localities: Lecane luna/L. closterocerca, Brachionus angularis / Hexarthra fennica / Anuraeopsis fissa, Brachionus plicatilis / Hexarthra fennica (in brackish ponds) and Keratella procurva / Filinia longiseta. This indicates the shared ecological preferences of these species.

b) Temporary ponds and flowing waters

Mean: $5.60 \mathrm{spp} /$ pond. More species can be found in these habitats. Lecanidae were frequent; 8 species occurred in samples from these waters.

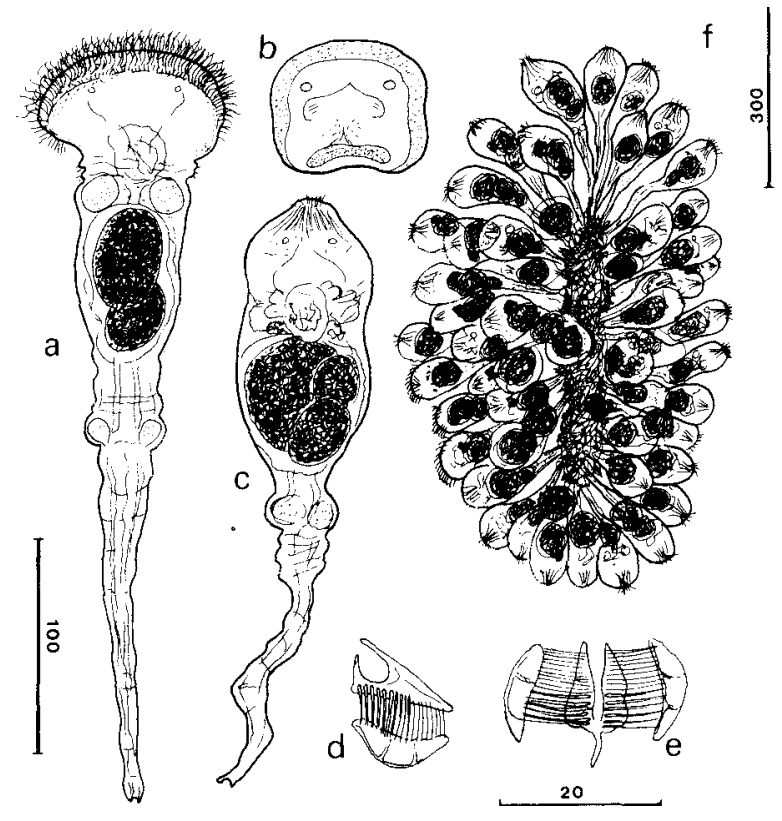

Figure 7. a) Lacinularia elliptica (loc. 2); b) shape of corona; c) contracted specimen; d) mastax (lateral); $e$ ) mastax (frontal); f) colony. Scale in $\mu \mathrm{m}$.
Lecane closterocerca, L. luna and L. bulla preferred temporary ponds, but also occurred in streams. Especially remarkable was the coexistence of Mytilina ventralis and Lophocharis salpina, both typical benthic species. Bdelloidea rotifers were found in all the samples from flowing waters. Lepadella patella occurred in $70 \%$ of these samples and Testudinella patina was a frequent inhabitant of temporary pools.

c) Artificial waters

Mean: $5.42 \mathrm{spp} /$ pond. Relatively diverse species assemblages were found in samples from artificial pools. Thus, 3 Brachionidae and 6 Lecanidae were found in artificial waterbodies. Bdelloid species were collected in $80 \%$ of localities. Keratella procurva was found in a northeastern pool of the island. In fact, many planktonic species as Anuraeopsis fissa, Hexarthra fennica, Polyarthra dolichoptera and Trichocerca rattus, have colonized the water of washing pools and drinking troughs.

\section{DISCUSSION}

This survey has added 33 new reports for $\mathrm{Mi}$ norca (table 1), and 29 for the Balearic Isles. A low level of species abundance is observed (5.26 species/locality), but we must take into account that only three surveys were made (February, April and July 1987).

The presence of benthic species as zooplankters was not unusual in permanent ponds, many Lecanidae (mainly Lecane luna, L. closterocerca and L. nana) and Bdelloidea were coliected from these environments. This is a consequence of the low level of water and the capability of these species to migrate from the bottom. Environmental instability permits greater species abundance in ephemeral waters and streams, where the composition of communities was constituted mainly by littoral rotifers that lived among macrophytes.

Passive dispersal of rotifers facilitates the colonization of farm ponds and other artificial waterbodies. This colonization is influenced by abiotic factors (temperature, water chemistry) and biotic factors (food availability, predation, competition). These local environmental conditions determine the composition of communities. The absence of 

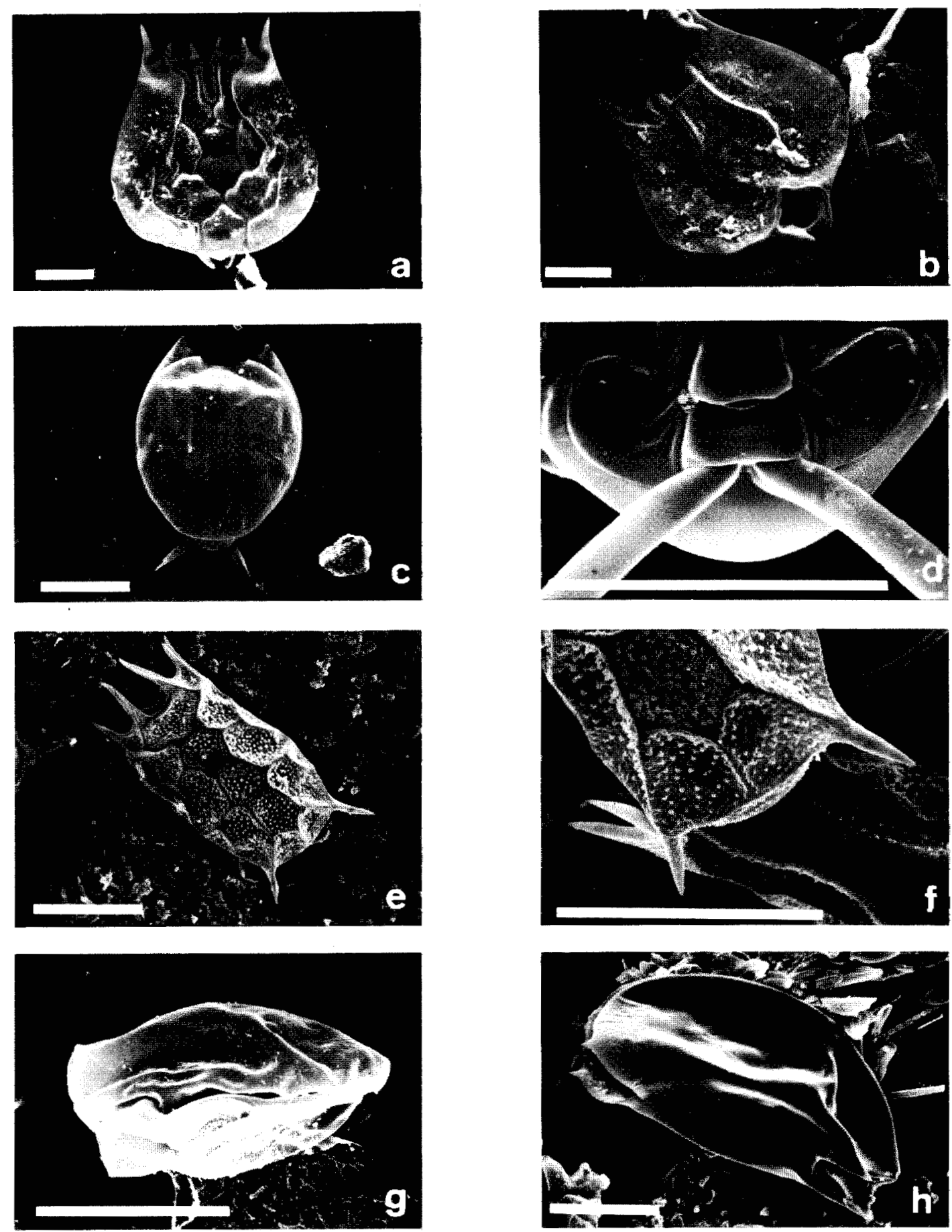

Figure 8.- a) Brachionus bidentata f. testudinarius (dorsal view, loc. 22); b) Brachionus bidenrata f. testudinarius (ventral view); c) Lecane luna (dorsal view, loc. 19); d) Lecane luna (toes insertion, loc. 19); e) Keratella procurva (dorsal view, loc. 20); f) posteromedian plaques of $K$. procurva; g) Anuraeopsis fissa (lateral view, loc. 9); h) Mytilina ventralis (lateral view, loc. 26). Scale bar $50 \mu \mathrm{m}$. 
planktonic rotifers from genus Synchaeta, and the poor abundance of Keratella species in the island, may be due to the small size of the freshwaterbodies studied.

Focusing on zoogeographical aspects, the most notable is the occurrence of Keratella procurva in many localities (20, 30, 35 and 38). K. procurva is considered as a subtropical species, although it was recorded in northafrican freshwaters (CousseMENT 6 Dumont, 1980). The only report from the Iberian Peninsula is given by Catalan (1986), who found $\boldsymbol{K}$. procurva in an artificial pool from Catalonia (NE Spain). Thus, it is not probable that this species has recently colonized Minorca from the Peninsula. It is more likely that this species has arrived in the island coming from Africa, and it may be an example of an opportunistic southern species occupying suitable habitats. This is also probably the case of the colonization of a pool by the tropical species Lacinularia elliptica.

Rotifer communities from Minorca inland waters are not so different from communities from the waters with similar ecological characters of the Iberian Peninsula, relatively close. Further surveys in the island surely will add new reports on its rotifer fauna.

\section{ACKNOWLEDGEMENTS}

Field work was carried out by J. LL. Pretus. Dr. W. Koste confirmed determination of Lacinularia elliptica. I would like to thank Dr. R. J. Shiel and Dr. M. R. Miracle for the revision of the manuscript and Laura Serrano for correcting the language. I want also to express my gratitude to the staff of the Servei de Microscòpia Electrònica de la Universitat de Barcelona.

\section{RESUMEN}

\section{CONTRIBUCIÓN AL CONOCIMIENTO DE LA FAUNA DE ROTÍFEROS (ROTIFERA: MONOGONONTA) DE LAS AGUAS INTERIORES DE LA ISLA DE MENORCA (ISLAS BALEARES, ESPANA)}

Se han identificado 44 especies de rotíferos obtenidos en muestreos realizados en lagunas permanentes, temporales y en aguas artificiales de la isla de Menorca. La mayor parte de ellos son nuevos hallazgos para la isla y 29 constituyen nuevas citas para las Baleares. Las familias Brachionidae y Lecanidae son las más frecuentes, y ambas aportan la mitad de los taxones. Se citan las diferentes formas («Formenkreis») y taxones hallados y se presentan dibujos originales y microfotografías en SEM de diversas especies; la especie subtropical Keratella pro. curva (Thorpe, 1912) se encuentra ampliamente distribuida en la isla, lo que le da un gran interés biogeográfico. Se describen también las asociaciones específicas más frecuentes y la composición de las comunidades propias de los hábitats estudiados.

\section{Bibliography}

Amsellem, J. \& P. Clement, 1980. A simplified method for the preparation of rotifers for transmission and scanning electron microscopy. Hydrobiologia 73: 119-122.

Catalan, J., 1986. Aproximación a la composición y organización del Neuston. Oecologia Aquatica 8: 25-38.

Coussement, M. \& H.J. Dumont, 1980. Some peculiar elements in the rotifer fauna of the Atlantic Sahara and of the Atlas Mountains. Hydrobiologia, 73: 249-254.

De RidDER, M., 1967. Quelques rotiferes de Majorque. Bull. Nat. Belg. 48 (8):409-418.

Dumont, H.J., 1983. Biogeography of Rotifers. Hydrobiologia 104: 19-30.

HARring, H.K. \& F.J. Myers, 1926. The Rotifer fauna of Wisconsin. IIl. A revision of the genera Lecane and $\mathbf{M o}$ - nostyla. In: J. CRAMER (ed.), The Rotifer Fauna of Wisconsin, 297-446. Trans. Wisc. Acad. Arts Sci. Lett. 825 pp.

HofMANN, W., 1977. The influence of abiotic environmenta factors on population dinamics in planktonic rotifers. Arch. Hydrobiol. Beih. 8: 77-83.

Koste, W., 1978. Rotatoria. Die Radertiere Mitteleuropas. Bestimmungswerk begründet von Max Voigt. 2 vols. Borntraeger, Stuttgart.

MARgALEF, R., 1951. Materiales para la hidrobiología de la isla de Ibiza. P. Inst. Biol. Apl. 8: 9-70.

Margalef, R., 1952. Materiales para la hidrobiología de la isla de Menorca. P. Inst. Biol. Apl. 11: 5-112.

Margalef, R., 1953. Materiales para la hidrobiología de la isla de Mallorca. P. Inst. Biol. Apl. 15: 5-111.

Pretus, J. L., 1989. Limnología de la Albufera de Menorca (Menorca, España). Limnética 5: 69-81. 